\title{
The Effect of Reading Involvement through Open-Ended Strategy vs. Fill-in- the- Blanks Strategy on Young EFL Learners' Reading Comprehension Ability
}

\author{
Rita Salehi Sepehr (Corresponding author) \\ Department of Language and Linguistics \\ Islamic Azad University-UAE Branch, Dubai, UAE \\ 17 Alessia Crt. Richmond Hill, Ontario, L4B 3Z5 Canada \\ E-mail: rita_sepehr@yahoo.com \\ Esmaeil Bagheridoust \\ Graduate Department of TESL and Translation Studies \\ Islamic Azad University-South Tehran Branch, Iran \\ E-mail: e_bagheridoust@azad.ac.ir \\ Massood Yazdani Moghaddam \\ Graduate Department of TESL and Translation Studies \\ Islamic Azad University, Garmsar Branch \\ E-mail: mym1300@gmail.com
}

Received: 29-05-2014

doi:10.7575/aiac.ijalel.v.3n.6p.124
Accepted: 13-07-2014

Published: 01-11-2014

URL: http://dx.doi.org/10.7575/aiac.ijalel.v.3n.6p.124

\begin{abstract}
The present study investigated the extent to which an instructional framework of integrating strategy instruction (openended strategy and fill-in-the blanks strategy) with motivation- support affected on reading result for young EFL learners. The central area of exploration included a comparison among three approaches to reading instruction: First, fill-in-the blanks strategy intervention; second, open-ended strategy intervention; and last, a control group which received the conventional reading strategies. The participants were sampled from amongst a group of seventy-seven pre-intermediate EFL learners in a language school in Tehran- Iran based on convenient sampling technique. For the sake of measurement, the researchers administered PET and CELT along with reading strategy based-test to quantify the participants' current level of knowledge as well as the degree of achievement after treatment. For measurement's sake, different types of tests such as PET, reading comprehension test (CELT), and reading strategy based- test were employed to quantify the participants' current level of knowledge as well as the degree of achievement before and after instruction. The result of the present study indicated that the experimental groups had a significant improvement over the control group. Also, the level of learners' reading engagement during classroom work mediated the instructional effects on reading outcomes. The results of this study can be to the benefit of both EFL and ESL teachers to teach reading comprehension using the student's critical mind as well as critical involvement in the reading tasks.
\end{abstract}

Keywords: reading comprehension, reading involvement, reading strategies, critical thinking, metacognition

\section{Introduction}

In the world today, teaching and learning the English language skills is a great concern of almost all educational organizations worldwide. In a foreign language context, Iranian context- the concern of this research- it cannot be denied that reading is a skill of prime importance among the four major language skills since reading expands and improves EFL learners' language awareness. Therefore, it is essential that school system continue to not only improve methods of teaching students how to read, but also to understand what they have read. Pardo (2004) suggests that reading becomes better with practice, and comprehension improves better through more reading practice. Likewise, Koda (2004) points out that strategic reading can compensate for learners' comprehension

insufficiency on the one hand and evolve their critical thinking on the other hand. Alexander and Jetton (2000) state: "reading studies demonstrate that:

Successful comprehension does not take place automatically, rather successful comprehension depends upon directed cognitive attempt, referred to as metacognitive processing, which includes knowledge about and rules of reading processing. During reading, metacognitive processing is declared via strategies, which are procedural, purposeful, effortful, strong-willed, fundamental, and facilitative in nature and the reader must deliberately or purposefully or eagerly appeal strategies. (p. 295) 


\section{A Glimpse at Types of Reading Strategies}

Strategies can be defined as conscious activities that learners take to attain desired goals, but a skill is a strategy that has become automatic. This characterization underlines the active role that readers play in strategic reading. Anderson (2003) stresses that as learners consciously acquire and practice particular reading strategies, the strategies move from conscious to unconscious, also from strategy to skill. The purpose for explicit strategy instruction is to transfer readers from conscious control of reading strategies to unconscious use of reading skills. Faggella-Luby and Deshler (2008) identified some strategies demonstrated regularly as the most effective reviews: applying explicit education to teach text structure (e.g., story elements in narrative passages), summarizing, self-monitoring, and self-questioning as well. As another types of reading comprehension strategies, we can point out scanning, skimming, guessing the meaning of unfamiliar words from context, making Inference, etc. However, what this paper is centered upon is open-ended and Fill-in-the blanks strategies that later on delineated in depth.

\section{Open-ended vs. Fill-in-the blanks strategies}

This study is by nature based on the reading theory known as Constructivism, which describes the process of knowledge construction. In this regard, Pakhhare (2007) claims that by engaging learners in reading tasks, teachers not only reinforce learners' knowledge of content, but also supply them with chances to evolve their understanding, vocabulary and study mastery without interrupting content learning. The rationale for the explicit instruction of reading comprehension skills is that employing comprehension strategies has highly been effective in improving understanding (National Reading Panel, 2002).

Constructivism views the nature of learners as self-directed, creative, and innovative. From the social constructivist viewpoint, the purpose in education is to become creative and innovative through analysis, conceptualizations, and synthesis of prior knowledge to create new knowledge. Flowerday and Schraw (2000) emphasize that in line with the constructivist and motivation theories, granting learners control of and engagement in the learning experience allows them to build up their own interpretation of the reading materials rather than be passive recipients of the information. That is, involving learners in the decisions regarding their reading activities should enhance their intrinsic motivation to learn and read (Randi \& Corno, 2000). At the same time, Randi and Corno (2000) suggest that the use of choice of reading material in the classroom enhances children's motivation, attempt, and performance. Furthermore, Erkaya (2005) claims that reading literary text can direct students to be critical thinkers. He also indicates that when students read, they interact with the text and interpret what they read and such analysis makes them to be more creative and critical. Constructivism also declares that purposeful learning takes place within authentic learning tasks (Brown and Adams, 2001). One structure of constructivist learning referenced in the literature is Inquiry-Based Learning (IBL). Inquiry-based learning may take place in the best way through the implementation of projects (Wilhelm, J., Sherrod, S. \& Walters, K., 2008). Project-based learning (PBL) is an approach that involves groups of learners in open-ended assignments, where they are encouraged to continuously search for information and assess their findings (Prince \& Felder, 2006). The purpose of this research was to involve learners in reading activities to encourage them to think critically by using their background knowledge and their new knowledge in the democracy atmosphere. In other words, this study aimed to investigate the influences of direct reading strategy instruction, on developing Iranian students' reading comprehension, metacognitive awareness of reading strategies, and attitudes toward reading.

\section{Fill-in- the-Blanks strategy}

In this kind of teaching reading, the researchers designed each reading lesson with the format of six types of reading related activities.

- Vocabulary (pre-reading activities) fill-in the-blanks form.

- Fill-in- the-blanks form of a short story related to the main passage.

- Some general questions regarding the theme of the passage.

- A pre-reading activity having the form of a fill-in the-blanks story.

- Asking students to fill-in-the-blanks with their favorite part of speech.

- Using some multiple-choice typed questions to establish reading.

\section{Open-ended strategy}

In this type of reading treatment, we only changed the reading passage into a story without the last part, therefore we asked all students in the class to think about the end of the story and compose it in the way they liked before reading the last paragraph of the story.

\section{Method}

\subsection{Participants}

The target population to which the results of this study will be generalized is the Iranian pre-intermediate EFL learners who study English at some language schools in Tehran-District 8. Out of this population the researchers selected the participants of the present study who were seventy-seven 'EFL students sifted out of 100 pre-intermediate learners of two English schools in Tehran and then based on convenient sampling three intact groups finally took part in the research. Due to the limitation of gender factor in educational system participants were either female or male. The average age of the participants was 13-17. Apart from the students, three teachers and the researchers conducted and 
managed the reading classes based on the three approaches of teaching reading among conventional, Open-ended strategy, and Fill-in-the- blanks strategy. The sample population was the true representative sample of the target population because the researchers administered homogenization test to approve of the normality test. The result of homogenization process guaranteed the degree of generalization the researchers determined after the research was carried out. Regarding the number of the students in each class the researchers had between 15 and 18 students in each group as the policy of the language school did not allow a class to have more students in one class.

\subsection{Design}

In this study the researchers employed the pretest- posttest intact groups analysis. More specifically, they employed the quasi- experimental research since the randomization of the participants of this study was not possible. In this kind of design both control group and experimental groups were examined for change due to the impact of the conventional and newly developed treatment.

\subsection{Procedure}

This research was carried out over a 12 weeks school semester program. The researchers selected 77 participants in three intact groups. To lead this research in the proper way, a test of homogeneity (PET) was essential for the purpose of the normality test. In order to increase the precision of the results and to control as many as extraneous factors as possible, the homogeneity of the instructional material, course objectives, whole-term syllabus and even the daily lesson planned were strictly controlled. The next step was to conduct the experimental treatment. Meanwhile, all participants were at pre- intermediate level and they studied the same reading book. This classroom based experimental study examined the effects of two different kinds of reading strategies: Fill-in-the blanks strategy and open-ended strategy. In order to investigate the possible effects of these reading strategies on the learners' reading comprehension ability, the homogeneous participants were divided into three groups. The three groups worked on the same reading materials of the school textbook while the only difference which considered as the focus of the study was that the teacher conducted Fill-in-the blanks and Open-ended strategies as reading comprehension strategies for group (B) and group (C) as the experimental groups, respectively. Group (A) that is, control group lacked such reading activities and received conventional reading activities. The first week was devoted to two samples essence for familiarization purposes (strategy awareness week).

In the first four weeks reading involvement strategies were divided in a way that 70 percent was expected of the teacher and 30 percent was expected of students. Then in the second four weeks, the percentage of reading involvement strategies between teacher and students was equal that is, 50 percent to teacher and 50 percent to students. And in the last four weeks, the divisions of the reading involvement strategies were reversed, in other words, 30 percent to teacher and 70 percent to students.

\subsection{Instruments}

Over a period of two months that is to say, (12 sessions of instruction and two sessions for pre- test and post test) the same teacher gave a post-test including the same multiple- choice cloze passage test as a sample of reading achievement test to experimental and control groups at the end of the semester to consider which group performed efficiently. The experimental and control groups' performances on the multiple-choice cloze passage as a sample of reading proficiency test means were compared through One-Way ANOVA. In the subsequent analysis, a reading proficiency post-test developed by Fowler and Coe (1976) was administered and One-way ANOVA was utilized to compare the obtained adjusted means. After scoring, descriptive statistics was performed on the tests, including mean, standard deviation, and variance. Then to investigate the significant differences on the three groups' performances, One-way ANOVA and skewness ratio was applied to the results of three groups' means in order to find out whether the possible differences were statistically significant. Finally, the Tukey HSD post-hoc analysis of Scheffe test was conducted to determine the significant differences at the .05 Alpha level among the research groups' means since we have more than three independent variables interacting with one dependent variable.

The participants' performances were scored in the following way: each correct answer in the multiple choice questions received 0.5 point and each incorrect answer received 0 point and minus point was not considered. The total score given to pre-test and the post-test was also 20. This procedure was applied in the tests conducted during the present study throughout the whole courses. Then, the participants' scores in both groups were calculated and subjected to the statistical analysis. The impact of this great shift of reading involvement was measured, and the elicited data was analyzed to figure out if such strategic-based reading assisted learners to become better readers.

\section{Data Analysis}

The inquirers delineates the statistical procedures she has manipulated, among 77 number of participants, after the data collection phase to approve of the conceived null-hypotheses at the outset of the study. Using SPSS version 18, the following statistical tests have been operated to make sure that the statistical techniques employed are logically and mathematically acceptable. Based on the variables taken into account in this research, i.e., Reading Comprehension, Fill-ins, and open- ended techniques, the design of the study with respect to the research question and the problem posed is assumed to be a quasi-experimental research design. One-Way ANOVA analysis is mainly employed to corroborate the standing differences between the three groups of participants in this study.

For the analysis part, the following sets of assumptions were met at first:

- Independent variable consists of two or more categorical independent groups, 
- Dependent variable is either interval or ratio (continuous)

- Dependent variable is approximately normally distributed for each category of the independent.

- Equality of variances between the independent groups (homogeneity of variances).

\subsection{Reiteration of the Questions and Hypotheses}

Based on the research questions, i.e., is there any reliable difference between the young EFL learners who develop reading comprehension ability using Fill-in-the blanks strategy as opposed to open-ended strategy?, Does the use of reading involvement through open-ended strategy have any impact on the improvement of young Iranian EFL learners' comprehension ability? Does the use of reading involvement through Fill-in-the blanks strategy have any reliable effect on the improvement of EFL Iranian young learners' comprehension? The inquirers formulated the following nullhypotheses:

H0-1: There is no reliable difference between the use of open-ended strategy vs. Fill-in-the blanks strategy in improving EFL young learners' reading comprehension ability.

H0-2: The use of reading involvement through open-ended strategy does not have any reliable impact on the improvement of EFL young learners' comprehension ability.

H0-3: The use of reading involvement through fill-in-the blanks strategy does not have any reliable effect on the improvement of EFL young learners' comprehension ability.

H0-4: There is no significant difference between the use of the conventional, fill-ins, and open ended reading methods.

To testify the above null-hypotheses the researchers went through the following statistical analyses and discussions. The descriptive statistics is used to represent data about mean, spread, skewness, kurtosis, minimum, and maximum scores. The test of normality is also used to show if scores are normally distributed, One Way ANOVA was employed at first to approve of no difference between the mean scores of the three groups of students and finally One way ANOVA was also employed for posttest analysis to find out the possible differences between the performance of the three groups in reading comprehension.

\subsection{Descriptive Statistics}

This part simply allotted to describe and summarize the data driven out of the preliminary analysis by SPSS, giving a clearer picture of the standing situation of participants prior to conducting any treatment. Table 4.1a below shows the descriptive statistics of the PET test at the start of the research process. As it is indicated in the table, the means score of the students is 22.83 and the standard deviation is 5.57 indicating a narrow spread of scores. The outliers of the PET test were put aside using the standard deviation pattern of $(+1$ and -1$)$ standard deviation. The final number of the participants was calculated as 77 candidates who belonged to three different classes.

Table1. Descriptive Statistics

\begin{tabular}{lrrrrrrr}
\hline & \multicolumn{1}{c}{ N } & Minimum & Maximum & Mean & \multicolumn{1}{c}{$\begin{array}{c}\text { Std. } \\
\text { Deviation }\end{array}$} & Kurtosis \\
& & & & & \multicolumn{1}{c}{ Statistic } & Std. Error \\
\cline { 2 - 8 } & Statistic & Statistic & Statistic & Statistic & Statistic & Static \\
PET Test & 100 & 13.00 & 34.00 & 22.8300 & 5.57421 & -.740 & .478 \\
Participants & 100 & 1.00 & 2.00 & 1.5500 & .50000 & -1.999 & .478 \\
Valid N & 100 & & & & & & \\
(listwise) & & & & & & & \\
\hline
\end{tabular}

Table 2. Detailed Descriptive Statistics

\begin{tabular}{|c|c|}
\hline \multicolumn{2}{|c|}{ Statistics } \\
\hline & PET Test \\
\hline Valid & 100 \\
\hline Missing & 1 \\
\hline Mean & 22.8300 \\
\hline Median & 23.0000 \\
\hline Mode & 24.00 \\
\hline Std. Deviation & 5.57421 \\
\hline Skewness & .074 \\
\hline Std. Error of Skewness & .241 \\
\hline Kurtosis & -.740 \\
\hline Std. Error of Kurtosis & .478 \\
\hline
\end{tabular}


In table2, the Skewness of 0.074 indicates that the scores of PET test are normally distributed since it is less than 0.1 . Based on the z-score analysis, roughly about $77 \%$ of the candidates were selected to take part in the study and 23 candidates were excluded from the study.

Table 3 gives a summary of how many participants are included (Control Group A =26; Experimental Group B=27, Experimental Group $\mathrm{C}=27$ ) in this study. This table shows that no cases are missing which is a merit to the study.

Table 3. Case Processing Summary

\begin{tabular}{|c|c|c|c|c|c|c|c|c|}
\hline & \multirow{2}{*}{\multicolumn{2}{|c|}{$\begin{array}{l}\text { CON Group A- EXP } \\
\text { Group B- EXP Group C }\end{array}$}} & \multicolumn{6}{|l|}{ Cases } \\
\hline & & & \multicolumn{2}{|l|}{ Valid } & \multicolumn{2}{|l|}{ Missing } & \multicolumn{2}{|l|}{ Total } \\
\hline & & & $\mathrm{N}$ & Percent & $\mathrm{N}$ & Percent & $\mathrm{N}$ & Percent \\
\hline \multirow{6}{*}{$\begin{array}{l}\text { Reading } \\
\text { PRETEST }\end{array}$} & dimension 1 & $\mathrm{CON}$ & 26 & $100.0 \%$ & 0 & $.0 \%$ & 26 & $100.0 \%$ \\
\hline & & Group A & & & & & & \\
\hline & & EXP & 27 & $100.0 \%$ & 0 & $.0 \%$ & 27 & $100.0 \%$ \\
\hline & & Group B & & & & & & \\
\hline & & EXP & 27 & $100.0 \%$ & 0 & $.0 \%$ & 27 & $100.0 \%$ \\
\hline & & Group C & & & & & & \\
\hline
\end{tabular}

Table 4 divided up by the three groups including one control and two other experimental groups, illustrates the descriptive statistics gained via pretest of reading. The details of the data are as follows: Control Group A, mean = 29.84, $\mathrm{Sx}=1.05$; Experimental Group B, 29.92, $\mathrm{Sx}=1.17$; Experimental Group C, mean = 29.22, $\mathrm{Sx}=1.21$.

7.3 One Way ANOVA, Pretest

The output of the omnibus ANOVA test, shown in Table 5 for the variable of Reading PRE Test Score, the omnibus ANOVA shows no statistical difference between groups. The main effect of group was statistical, F2, 77=.002, p $=$ .998 .

Table 5. Test of ANOVA

\begin{tabular}{llccccc}
\hline & & $\begin{array}{c}\text { Sum of } \\
\text { Squares }\end{array}$ & df & $\begin{array}{c}\text { Mean } \\
\text { Square }\end{array}$ & F & Sig. \\
\hline Reading & Between & .112 & 2 & .056 & .002 & .998 \\
PRETEST & Groups & & & & & \\
& Within Groups & 2731.088 & 77 & 35.469 & & \\
& Total & 2731.200 & 79 & & & \\
\hline
\end{tabular}

Comparisons (Table 6) using Tukey's contrasts found no statistical difference among Control Group A and Experimental Group B (mean difference $=-.079,95 \% \mathrm{CI}=3.83,-.39, \mathrm{~d}=-0.071, \mathrm{r}=-0.035, \mathrm{p}=.99$ ) nor between Experimental Group C and Control Group A (mean difference $=.079,95 \% \mathrm{CI}=3.99,-3.83, \mathrm{~d}=-0.070, \mathrm{r}=-0.035, \mathrm{p}$ $=.99$ ), the same story was true between Experimental Group B and Experimental Group C (mean difference $=.000$, 95\% CI $=3.87-.-3.87, d=0, r=0, p=1.00)$. Scheffe tests also accentuates the similar result, showing none of the comparisons was below $\alpha=.05$.

Table 7. Reading Pretest

\begin{tabular}{|c|c|c|c|}
\hline & CON Group A- EXP Group B- EXP Group & $\mathbf{N}$ & Subset for alpha $=0.05$ \\
\hline & & & 1 \\
\hline \multirow[t]{3}{*}{ Tukey HSD ${ }^{\mathbf{a}, \mathrm{b}}$} & CON Group A & 26 & 29.8462 \\
\hline & EXP Group B & 27 & 29.9259 \\
\hline & Sig. & & .999 \\
\hline
\end{tabular}

Homogeneous subset, the very last piece of the output from the One Way ANOVA, shows the results of the Tukey HSD post-hoc (Table 6). The test places all the three groups in one category. In the table none of the comparisons is statistical below $\alpha=.05$.

\subsection{Test Validation}

For having a valid test result, reliability is a necessity. So taking the cognizance of the foresaid line, the researchers met the standing reliability in her study.

In order to get the test reliability, KR-21 method (cited in Hatch \& Farhady, 1982) was utilized. The Nelson reliability was estimated as 0.9 . The ratios of skewness, statistic over standard error (0.40) was within the range of plus and minus 1.96.

\subsection{Descriptive Statistics. Post Test}

In this part of the study the result of participants' scores in posttest of Reading Comprehension, to be analyzed and clarified.

Table 8 divided up by the three groups (a control and two experimental ones), illustrates the resulted descriptive 
statistics as follows: Control Group A, mean $=32.11, \mathrm{Sx}=1.05$; Experimental Group B, 37.07, $\mathrm{Sx}=1.10$; Experimental Group $\mathrm{C}$, mean $=40.18, \mathrm{Sx}=1.10$.

\subsection{Test of ANOVA, Posttest}

This part deals with the posttest results which are gained through One Way ANOVA test. The output of the omnibus ANOVA test, shown in Table 9 For the variable of Reading POST Test Score, the omnibus ANOVA unveils significant statistical difference between groups. The main effect of group was statistical, F2, 77=13.78, $p=.000,<.05$.

Table 9.a Test of ANOVA

\begin{tabular}{llccccc}
\hline & & $\begin{array}{c}\text { Sum of } \\
\text { Squares }\end{array}$ & df & $\begin{array}{c}\text { Mean } \\
\text { Square }\end{array}$ & F & Sig. \\
\hline Reading POST & Between & 875.408 & 2 & 437.704 & 13.787 & .000 \\
& Groups & & & & & \\
& Within Groups & 2444.580 & 77 & 31.748 & & \\
& Total & 3319.988 & 79 & & \\
\hline
\end{tabular}

Comparisons (Table 9) using Tukey's contrasts found a significant statistical difference among Control Group A and Experimental Group B (mean difference $=-4.958,95 \% \mathrm{CI}=-1.25,-8.65, \mathrm{~d}=-4.612, \mathrm{r}=-0.917, \mathrm{p}=.006<.05$ ), the same story witnessed between Experimental Group C and Control Group A (mean difference $=8.06,95 \% \mathrm{CI}=11.79,4.36, \mathrm{~d}$ $=-7.504, \mathrm{r}=-0.966, \mathrm{p}=.00<.05)$. It is worthwhile nothing that no significant difference observed between Experimental Group B and Experimental Group C (mean difference $=3.111,95 \% \mathrm{CI}=6.77,-.55, \mathrm{~d}=-2.827, \mathrm{r}=-0.816$, $\mathrm{p}=.11)$.

Scheffe tests also accentuates the similar result, showing significant difference between Group A and B $(p=.006<.05)$ from one side and significant difference between Group $\mathrm{C}$ and $\mathrm{A}(\mathrm{p}=000<.05)$. No significant observed between Experimental groups of $\mathrm{B}$ and $\mathrm{C}(\mathrm{p}=.126)$

Table 9.b Reading Post Test

\begin{tabular}{|c|c|c|c|c|c|c|c|c|c|c|}
\hline \multicolumn{11}{|c|}{ Multiple Comparisons } \\
\hline \multirow{3}{*}{\multicolumn{2}{|c|}{ Dependent Variable }} & \multirow{2}{*}{\multicolumn{2}{|c|}{$\begin{array}{l}\text { (I) CON Group A- } \\
\text { EXP Group B- EXP } \\
\text { Group C }\end{array}$}} & \multirow{2}{*}{\multicolumn{2}{|c|}{$\begin{array}{l}\text { (J) CON Group A- } \\
\text { EXP Group B- EXP } \\
\text { Group C }\end{array}$}} & \multirow{2}{*}{$\begin{array}{c}\text { Mean } \\
\text { Difference } \\
(\mathrm{I}-\mathrm{J})\end{array}$} & \multirow[t]{2}{*}{$\begin{array}{l}\text { Std. } \\
\text { Error }\end{array}$} & \multirow[t]{2}{*}{ Sig. } & \multicolumn{2}{|c|}{$\begin{array}{l}95 \% \text { Confidence } \\
\text { Interval }\end{array}$} \\
\hline & & & & & & & & & Lower & Upper \\
\hline & & dimension? & $\mathrm{CON}$ & dimension 3 & EXP & $-495869^{*}$ & 154820 & 006 & $\begin{array}{l}\text { Bound } \\
-86587\end{array}$ & Bound \\
\hline \multirow{31}{*}{$\begin{array}{l}\text { Reading } \\
\text { POST }\end{array}$} & HSD & & Group & & Group & & & & & \\
\hline & & & A & & B & & & & & \\
\hline & & & & & EXP & $-8.06980^{*}$ & 1.54820 & .000 & - & -4.3698 \\
\hline & & & & & $\begin{array}{l}\text { Group } \\
\text { C }\end{array}$ & & & & 11.7698 & \\
\hline & & & EXP & dimension3 & $\mathrm{CON}$ & $4.95869^{*}$ & 1.54820 & .006 & 1.2587 & 8.6587 \\
\hline & & & Group & & Group & & & & & \\
\hline & & & $\mathrm{B}$ & & A & & & & & \\
\hline & & & & & EXP & -3.11111 & 1.53352 & .112 & -6.7760 & .5538 \\
\hline & & & & & $\begin{array}{l}\text { Group } \\
\text { C }\end{array}$ & & & & & \\
\hline & & & EXP & dimension3 & $\mathrm{CON}$ & $8.06980^{*}$ & 1.54820 & .000 & 4.3698 & 11.7698 \\
\hline & & & Group & & Group & & & & & \\
\hline & & & $\mathrm{C}$ & & A & & & & & \\
\hline & & & & & EXP & 3.11111 & 1.53352 & .112 & -.5538 & 6.7760 \\
\hline & & & & & Group & & & & & \\
\hline & & & & & $\mathrm{B}$ & & & & & \\
\hline & Games- & dimension2 & $\mathrm{CON}$ & dimension3 & EXP & $-4.95869^{*}$ & 1.52853 & .006 & -8.6486 & -1.2687 \\
\hline & Howell & & Group & & Group & & & & & \\
\hline & & & A & & $\mathrm{B}$ & & & & & \\
\hline & & & & & EXP & $-8.06980^{*}$ & 1.52863 & .000 & - & -4.3796 \\
\hline & & & & & $\begin{array}{l}\text { Group } \\
\text { C }\end{array}$ & & & & 11.7600 & \\
\hline & & & EXP & dimension 3 & $\mathrm{CON}$ & $4.95869^{*}$ & 1.52853 & .006 & 1.2687 & 8.6486 \\
\hline & & & Group & & Group & & & & & \\
\hline & & & $\mathrm{B}$ & & A & & & & & \\
\hline & & & & & EXP & -3.11111 & 1.56708 & .126 & -6.8918 & .6696 \\
\hline & & & & & $\begin{array}{l}\text { Group } \\
\text { C }\end{array}$ & & & & & \\
\hline & & & EXP & dimension3 & $\mathrm{CON}$ & $8.06980^{*}$ & 1.52863 & .000 & 4.3796 & 11.7600 \\
\hline & & & Group & & Group & & & & & \\
\hline & & & $\mathrm{C}$ & & A & & & & & \\
\hline & & & & & EXP & 3.11111 & 1.56708 & .126 & -.6696 & 6.8918 \\
\hline & & & & & Group & & & & & \\
\hline & & & & & $\mathrm{B}$ & & & & & \\
\hline
\end{tabular}

\footnotetext{
*. The mean difference is significant at the 0.05 level.
} 


\begin{tabular}{|c|c|c|c|c|c|}
\hline \multicolumn{6}{|c|}{ Reading POST } \\
\hline \multirow{6}{*}{ Tukey HSD ${ }^{\mathrm{a}, \mathrm{b}}$} & \multirow{2}{*}{\multicolumn{2}{|c|}{$\begin{array}{l}\text { CON Group A- EXP Group B- EXP } \\
\text { Group C }\end{array}$}} & \multirow[t]{2}{*}{$\mathrm{N}$} & \multicolumn{2}{|c|}{ Subset for alpha $=0.05$} \\
\hline & & & & 1 & 2 \\
\hline & dimension 1 & CON Group A & 26 & 32.1154 & \\
\hline & & EXP Group B & 27 & & 37.0741 \\
\hline & & EXP Group C & 27 & & 40.1852 \\
\hline & & Sig. & & 1.000 & .115 \\
\hline
\end{tabular}

Homogeneous subsets, Table 10, show the results of the Tukey HSD post-hoc tests.

The Test placed Group B and Group C together (the difference between them is $p=.115$, so the difference is not below $\mathrm{p}=.05$ ). The fact that group $\mathrm{A}$ is in a different column from the others means that there is a statistical difference between this groups and the others at the $\mathrm{p}=.05$ level.

Testing the research hypothesis\# 1

All the proposed hypotheses in this study are tested based on the result gained through One Way ANOVA tests (Pre and Post-tests).

The first of four suggested null hypotheses says "The use of reading involvement through fill-in-the blanks strategy does not have any reliable effect on the improvement of EFL young learners' comprehension ability".

Comparing the mean score, brought in Table 7, gained by Experimental Group B, the one used Fill-in-the blank strategy, in Pretest (mean =29.92) with the mean score, brought in table 10, gained by the same group in Post-test (mean $=37.07$ ), we can prove the reliable positive effect of the strategy on EFL young learners' comprehension ability, rejecting the proposed null hypothesis as well.

Testing the research hypothesis\# 2

"The use of reading involvement through open-ended strategy does not have any reliable impact on the improvement of EFL young learners' comprehension ability" is the second null hypothesis posed in the study.

By comparing the mean score, Table 7, by Experimental Group C, the one used open-ended strategy, in Pre-test (mean $=29.92$ ) with the mean score brought in table 10 by the same group in Post-test (mean $=40.18$ ), the reliable positive effect of open-ended strategy on EFL young learners' comprehension ability can be proven, and we can reject the proposed line as well.

Testing the research hypothesis\# 3

In previous hypothesis, we proved open-ended strategy is an effective way to improve reading comprehension ability. But in the third null hypothesis it is proposed that "Using open-ended strategy is not a more effective way to improve reading comprehension ability than using Conventional strategy". Such an idea can be rejected through studying the scores gained by two groups of participants; each used one of these strategies. Results in One Way ANOVA Pre-test illustrate no significant difference between the scores gained by control group $\mathrm{A}$ and the experimental one $\mathrm{C}(\mathrm{P}=.99)$ while in One Way ANOVA posttest, such significant difference $((\mathrm{P}=.000,<.05)$ is quite observable between the two groups.

Testing the research hypothesis\# 4

Based on the previous hypotheses proved up to here, both open-ended strategies vs. fill- in-the blanks strategy are positively effective in improving EFL young learners' reading comprehension ability. At this very point, we can reject the fourth or last hypothesis says "no reliable difference stands between the uses of open-ended strategy vs. Fill- in-the blanks strategy in improving EFL young learners' reading comprehension ability". Through the same route which has been used thus far and by studying the result of One Way ANOVA test (Reading Post Test), we can observe no significant difference $(\mathrm{P}=.112)$ among scores gained by students using the two strategies, rejecting this hypothesis too

\section{Results}

This study corroborated the two strategies of Fill-ins, and open- ended techniques can provide a fertile ground for young EFL learners' to progress their reading comprehension ability. In the present investigation the three strategies of Reading comprehension, Fill-ins, and open- ended utilized by three groups of students including control group A in which 26 number of students tried to uplift their reading skill ability through conventional way of Reading Comprehension, experimental group B with 27 participants using Fill-ins and experimental group C with 27 students tried the open-ended

techniques. Through One Way ANOVA test, the scores of students in each group, gained through taking two set of tests (pretest and posttest), analyzed and delineated by the researchers. The outcome of tests with their analysis used for rejecting the 4 posed null hypotheses in the study.

Comparing the mean scores each group's participants gained, the researchers proved the strategies of Fill-ins and especially open-ended play telling role in scaling up students' reading skills. No significant difference observed between the results reaped through using the two techniques in this probe, albeit the mean score between outcomes shows participants in experimental group C ( the one used open-ended strategy) outperform the counterparts in experimental 
group B ( the one used fill-ins strategy).

Through comparing results in Pretest and Post-test analyzed in One-Way ANOVA, the researchers also proved that the two strategies used among experimental groups are more effective ways to improve reading comprehension ability than using Conventional strategy.

\section{Discussion \& Conclusion}

The techniques conventionally used for teaching reading comprehension are so varied that language instructors mostly get confused to make the best choice possible. Among the different forms available, the inquirers selected three practical forms to study in order to find out which one wins the race of effectiveness. Based on the previous hypotheses proved up to here, both open-ended strategies vs. fill- in-the blanks strategy are positively effective in improving EFL young learners' reading comprehension ability. This research indicated that the explicit strategy instruction is effective in building up EFL students' knowledge and encouraging their use of reading strategies. That is, through the explicit strategy instruction, students can be taught not only what strategies are, but also how, why and when to use them. The findings imply that EFL learners need to promote their knowledge and use of reading strategies, and the explicit strategy instruction proves an effective way to help them achieve these goals.

\section{References}

Alexander, P. A., \& Jetton, T. L. (2000). Learning from text: A multidimensional and developmental perspective. In M. L. Kamil, P. B. Mosenthal, P. D. Pearson, \& R. Barr (Eds.), Handbook of reading research (Vol. 3, pp. 285-310). Mahwah, NJ: Erlbaum.

Anderson, N. J. (2003). Teaching reading. In D. Nunan (Ed.), Practical English language teaching (pp. 6786). New York: McGraw Hill Publishers.

Brown, J. C. \& Adams, A. (2001). Constructivist teaching strategies: Projects in teacher education. Springfield, IL: Charles C. Thomas.

Erkaya, O. R. (2005). Benefits of using short stories in the EFL context. The Asian EFL Journal, 8, 38-49.

Faggella-Luby, M., \& Deshler, D. D. (2008). Reading comprehension in adolescents with LD: What we know, what we need to know. Learning Disability Research and Practice, 23(2), 70-78.

Flowerday, T., \& Schraw, G., (2000). Teacher beliefs about instructional choice: A phenomenological study. Journal of Educational Psychology, 92(2), 634-645.

Koda, K. (2004). Insights into second language reading: A cross-linguistic approach. Cambridge: Cambridge University Press.

National Institute of Child Health and Human Development (2002). Report of the National Reading Panel, "Teaching Children to Read: An Evidence-Based Assessment of the Scientific Research Literature on Reading and Its Implications for Reading Instruction.” (NIH Publication No. 00-4769), Washington, D.C.: U.S Government Printing Office.

Pakhare, J. (2007). Effective Teaching: Reading Comprehension Strategies. Retrieved July 20, 2013 from www.buzzle.com

Pardo, L.S. (2004). What every teacher needs to know about comprehension. The Reading Teacher, 58 (3), 272-280.

Prince, M. \& Felder, R. (2006). Inductive teaching and learning methods: Definitions, comparisons, and research bases. Journal of Engineering Education, 95, 123-38.

Randi, J., \& Corno, L. (2000). Teacher innovations in self-regulated learning. In M. Boekaerts, P. R. Pintrich, \& M. Zeidner (Eds.), Handbook of self- regulation (pp. 651-685). San Diego: Academic Press.

Wilhelm, J., Sherrod, S. \& Walters, K. (2008). Project-based learning environments: challenging preservice teachers to act in the moment. The Journal of Educational Research, 101, 220-233. 
Table 4. Description of Reading Pre Test

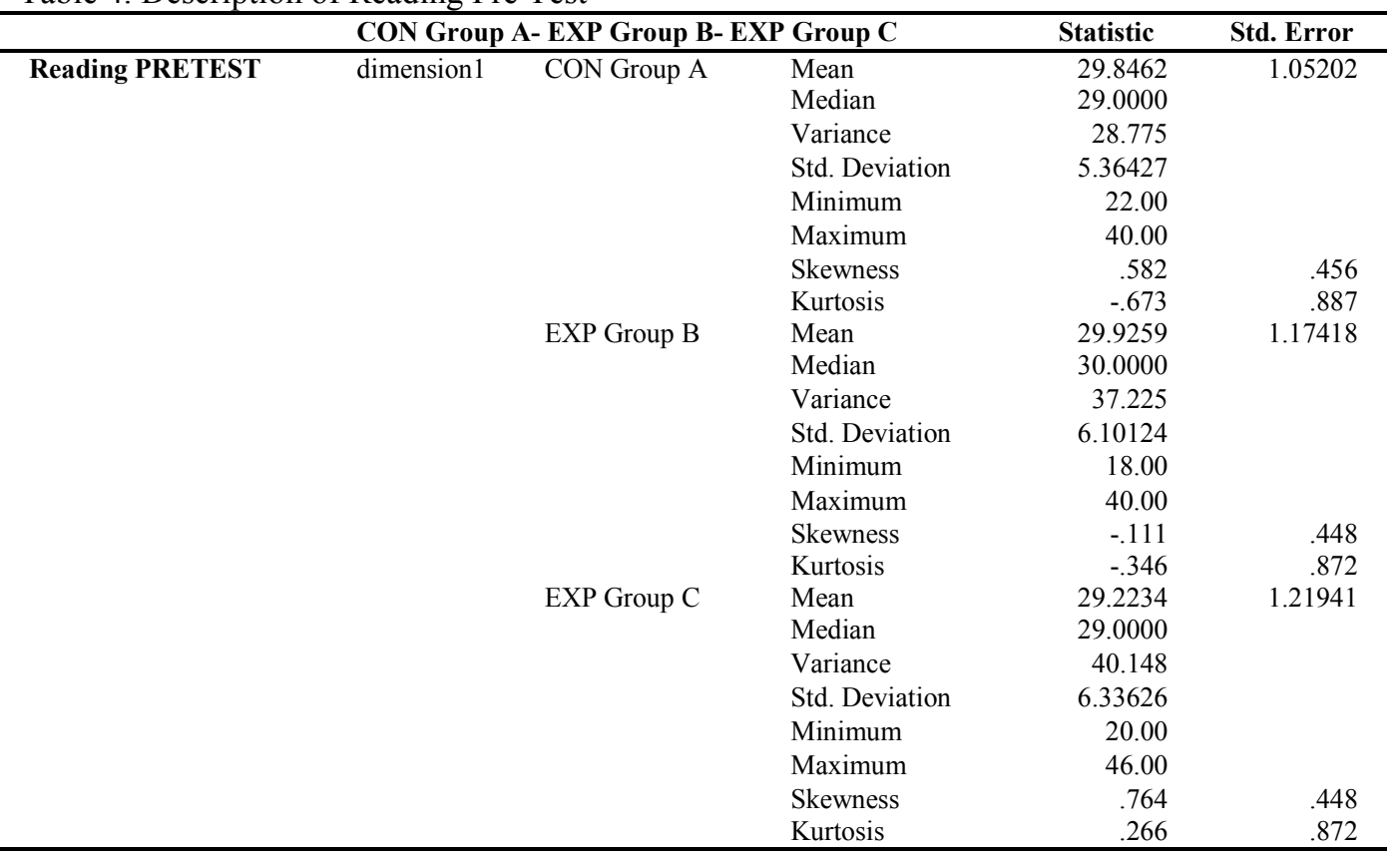

\section{Appendix B}

Table 6. Multiple Comparisons

\begin{tabular}{|c|c|c|c|c|c|c|c|c|c|c|}
\hline \multirow{2}{*}{\multicolumn{2}{|c|}{ Dependent Variable }} & \multirow{2}{*}{\multicolumn{2}{|c|}{$\begin{array}{l}\text { (I) CON Group A- } \\
\text { EXP Group B- EXP } \\
\text { Group C }\end{array}$}} & \multirow{2}{*}{\multicolumn{2}{|c|}{$\begin{array}{l}(\mathrm{J}) \text { CON Group A- } \\
\text { EXP Group B- EXP } \\
\text { Group C }\end{array}$}} & \multirow{2}{*}{$\begin{array}{c}\text { Mean } \\
\text { Difference } \\
(\mathrm{I}-\mathrm{J})\end{array}$} & \multirow[t]{2}{*}{$\begin{array}{l}\text { Std. } \\
\text { Error }\end{array}$} & \multirow[t]{2}{*}{ Sig. } & \multicolumn{2}{|c|}{$\begin{array}{l}95 \% \text { Confidence } \\
\text { Interval }\end{array}$} \\
\hline & & & & & & & & & Lower & Upper \\
\hline \multirow{36}{*}{$\begin{array}{l}\text { Reading } \\
\text { PRETEST }\end{array}$} & Tukey & dimension 2 & $\mathrm{CON}$ & dimension 3 & EXP & -07977 & 163641 & 999 & - & 3.8310 \\
\hline & HSD & & Group & & Group & & & & 3.9906 & \\
\hline & & & A & & $\mathrm{B}$ & & & & & \\
\hline & & & & & EXP & -.07977 & 1.63641 & .999 & - & 3.8310 \\
\hline & & & & & Group & & & & 3.9906 & \\
\hline & & & & & $\mathrm{C}$ & & & & & \\
\hline & & & EXP & dimension 3 & $\mathrm{CON}$ & .07977 & 1.63641 & 999 & - & 3.9906 \\
\hline & & & Group & & Group & & & & 3.8310 & \\
\hline & & & $\mathrm{B}$ & & A & & & & & \\
\hline & & & & & EXP & .00000 & 1.62090 & 1.000 & - & 3.8737 \\
\hline & & & & & Group & & & & 3.8737 & \\
\hline & & & & & $\mathrm{C}$ & & & & & \\
\hline & & & EXP & dimension 3 & $\mathrm{CON}$ & .07977 & 1.63641 & .999 & - & 3.9906 \\
\hline & & & Group & & Group & & & & 3.8310 & \\
\hline & & & $\mathrm{C}$ & & A & & & & & \\
\hline & & & & & EXP & .00000 & 1.62090 & 1.000 & - & 3.8737 \\
\hline & & & & & Group & & & & 3.8737 & \\
\hline & & & & & B & & & & & \\
\hline & Games- & dimension2 & $\mathrm{CON}$ & dimension 3 & EXP & -.07977 & 1.57653 & .999 & - & 3.7269 \\
\hline & Howell & & Group & & Group & & & & 3.8864 & \\
\hline & & & A & & B & & & & & \\
\hline & & & & & EXP & -.07977 & 1.61050 & .999 & - & 3.8098 \\
\hline & & & & & Group & & & & 3.9694 & \\
\hline & & & & & $\mathrm{C}$ & & & & & \\
\hline & & & EXP & dimension 3 & $\mathrm{CON}$ & .07977 & 1.57653 & .999 & - & 3.8864 \\
\hline & & & Group & & Group & & & & 3.7269 & \\
\hline & & & B & & A & & & & & \\
\hline & & & & & EXP & .00000 & 1.69283 & 1.000 & - & 4.0843 \\
\hline & & & & & Group & & & & 4.0843 & \\
\hline & & & & & $\mathrm{C}$ & & & & & \\
\hline & & & EXP & dimension 3 & $\mathrm{CON}$ & .07977 & 1.61050 & .999 & - & 3.9694 \\
\hline & & & Group & & Group & & & & 3.8098 & \\
\hline & & & $\mathrm{C}$ & & A & & & & & \\
\hline & & & & & EXP & .00000 & 1.69283 & 1.000 & - & 4.0843 \\
\hline & & & & & Group & & & & 4.0843 & \\
\hline & & & & & $\mathrm{B}$ & & & & & \\
\hline
\end{tabular}

*. The mean difference is significant at the 0.05 level. 
Table 8. Description of Reading Post Test

\begin{tabular}{|c|c|c|c|c|}
\hline \multirow{28}{*}{ Reading POST } & \multicolumn{2}{|c|}{ CON Group A- EXP Group B- EXP Group C } & Statistic & Std. Error \\
\hline & dimension1 CON Group A & Mean & 32.1154 & 1.05295 \\
\hline & & Median & 30.0000 & \\
\hline & & Variance & 28.826 & \\
\hline & & Std. Deviation & 5.36900 & \\
\hline & & Minimum & 25.00 & \\
\hline & & Maximum & 44.00 & \\
\hline & & Range & 19.00 & \\
\hline & & Skewness & .704 & .456 \\
\hline & & Kurtosis & -.443 & .887 \\
\hline & EXP Group B & Mean & 37.0741 & 1.10802 \\
\hline & & Median & 38.0000 & \\
\hline & & Variance & 33.148 & \\
\hline & & Std. Deviation & 5.75744 & \\
\hline & & Minimum & 20.00 & \\
\hline & & Maximum & 47.00 & \\
\hline & & Range & 27.00 & \\
\hline & & Skewness & -.880 & .448 \\
\hline & & Kurtosis & 1.697 & .872 \\
\hline & EXP Group C & Mean & 40.1852 & 1.10816 \\
\hline & & Median & 40.0000 & \\
\hline & & Variance & 33.157 & \\
\hline & & Std. Deviation & 5.75819 & \\
\hline & & Minimum & 28.00 & \\
\hline & & Maximum & 50.00 & \\
\hline & & Range & 22.00 & \\
\hline & & Skewness & -.512 & .448 \\
\hline & & Kurtosis & -.412 & .872 \\
\hline
\end{tabular}

